\title{
TRADITIONAL WEDDING COSTUME OF THE MRKOVIĆI IN MONTENEGRO: BETWEEN REAL HERITAGE AND FOLK CONSTRUCTION (MATERIALS OF THE RUSSIAN EXPEDITIONS IN 2012-2014)
}

\author{
Alexander Novik, Andrey Sobolev
}

\begin{abstract}
The traditional clothing of the Mrkovići Muslim ethno-local group in Montenegro began to change at the turn of the 21st century in response to several factors. Firstly, this clothing was more and more reserved exclusively for ritual (and festive) occasions. Secondly, the group demonstrated increased interest in its own history and culture. And, thirdly, the group confronted challenges associated with globalization processes by transforming its traditional clothing. This paper recounts the results of fieldwork conducted by the recent Russian Balkan expeditions. We briefly outline the history of the prototypical oriental female dress and provide commonly used names for its elements. We then describe a costume variant common among the Mrkovići in the 19th and 20th centuries and give the dialectal names for its elements. We have recorded the 21 st century transition to a new variant of the wedding costume, dominated by the color white, which is motivated by aesthetic, pragmatic, mythological, and religious factors. Finally we describe this contemporary costume and name its details. The specific combination of archaic and innovative, inherited and borrowed elements shapes the peculiar profile of the Mrkovići culture as a whole and their traditional wedding costume in particular.
\end{abstract}

Keywords: Balkan expeditions, Balkan Muslim Slavs, ethno-confessional groups, ethno-local groups, history of costume, identity markers, Montenegro, Mrkovići tribe, names of costume elements, wedding costume

\section{INTRODUCTION}

The inhabitants of approximately ten villages in the far southwest of Montenegro, to the southeast of the city of Bar (Alb. Tivari), make up the ethno-local Mrkovići community (Fig. 1), also known as Mrkojevići, and as Mërkot in Albanian (Jovičević 1922). The members of this community have used and are still using a specific dialect of the Serbo-Croatian language (Vujović 1969). The northern, southern, and eastern borders of the Mrkovići settlements are shared 


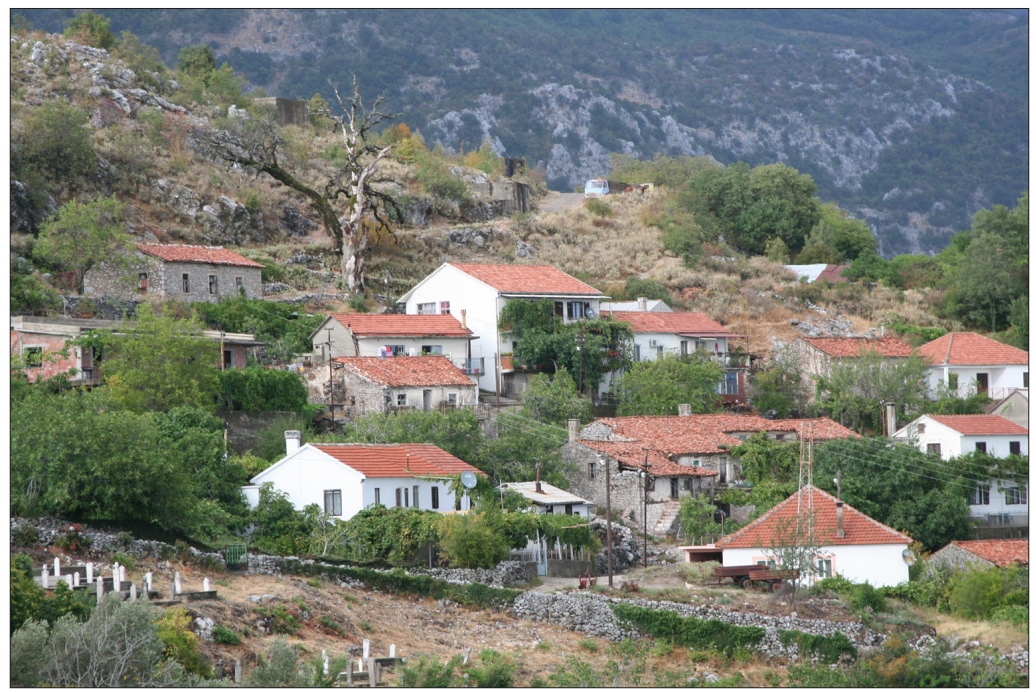

Figure 1. View of Dabezići mountain village. Photograph by Alexander Novik, September 2012.

with the Albanian speaking regions of Shestani, Ulqini (Serb.-Croat. Ulcinj), and Ana e Malit (Ahmetaj 2006; Šekularac \& Pavlović 2012). The overwhelming majority of the Mrkovići converted to Sunni Islam in the 17th and 18th centuries, and the group now constituting a rather insular local ethno-confessional population of about 3000 (Metanović 2005; Grgurević 2013) has historically evolved a separate existence (Metanović 2001) ${ }^{1}$ that has nevertheless escaped notice by foreign scholars during the 20th and 21st centuries.

In a series of Balkan expeditions conducted by the Russian Academy of Sciences (RAS) and Saint Petersburg State University (SPbSU) in 2012 through to 2014 (cf. Sobolev \& Novik 2013), Andrey Sobolev (Institute for Linguistic Studies (ILS) of the RAS and SPbSU), Alexander Novik (Museum of Anthropology and Ethnography (MAE) "Kunstkamera" of the RAS and SPbSU), Denis Ermolin (MAE RAS), Maria Morozova (ILS RAS and SPbSU), Alexandra Dugushina (MAE RAS), and Anastasia Makarova (ILS RAS) all took part in research activities organized in the Mrkovići settlement area.

According to literature and our own observations, this group's most important differentiating markers are its collective notion of the historical unity of all the Mrkovici and its confessional adherence to Islam, possibly supplemented by traditional costume, vernacular architecture (Fig. 2), textile crafts (Fig. 3), various kinds of handiwork, traditional cooking, traditional etiquette, and a fading local dialect. This research deals with the traditional wedding costume of the Mrkovici, which began to change substantially at the turn of the 21 st century. 


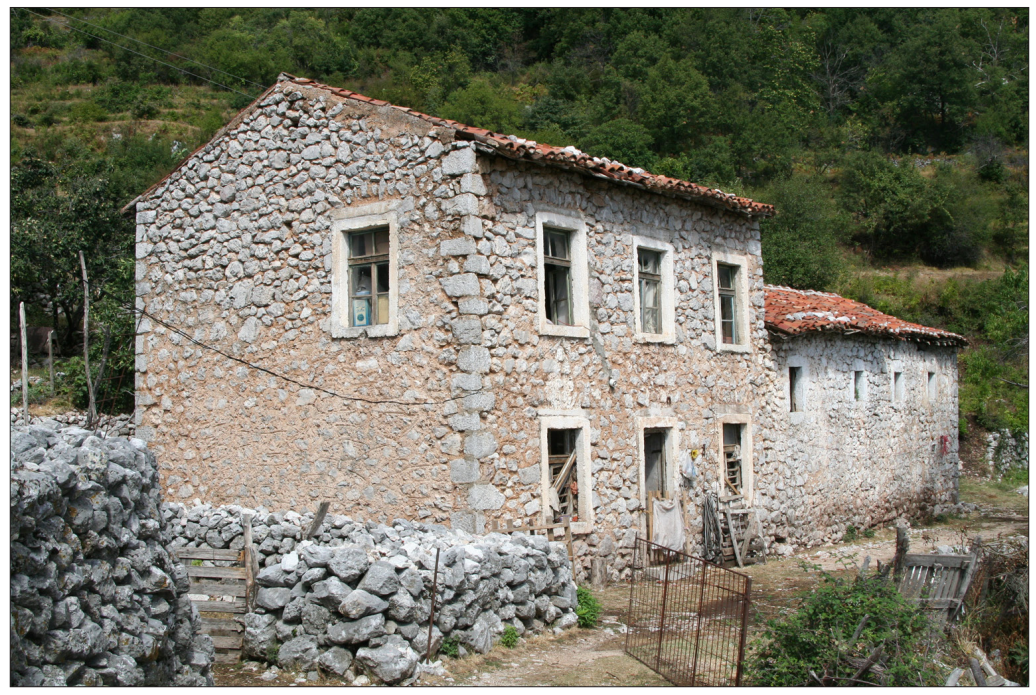

Figure 2. Traditional stone house. Village of Lunje. Photograph by Alexander Novik, September 2012.

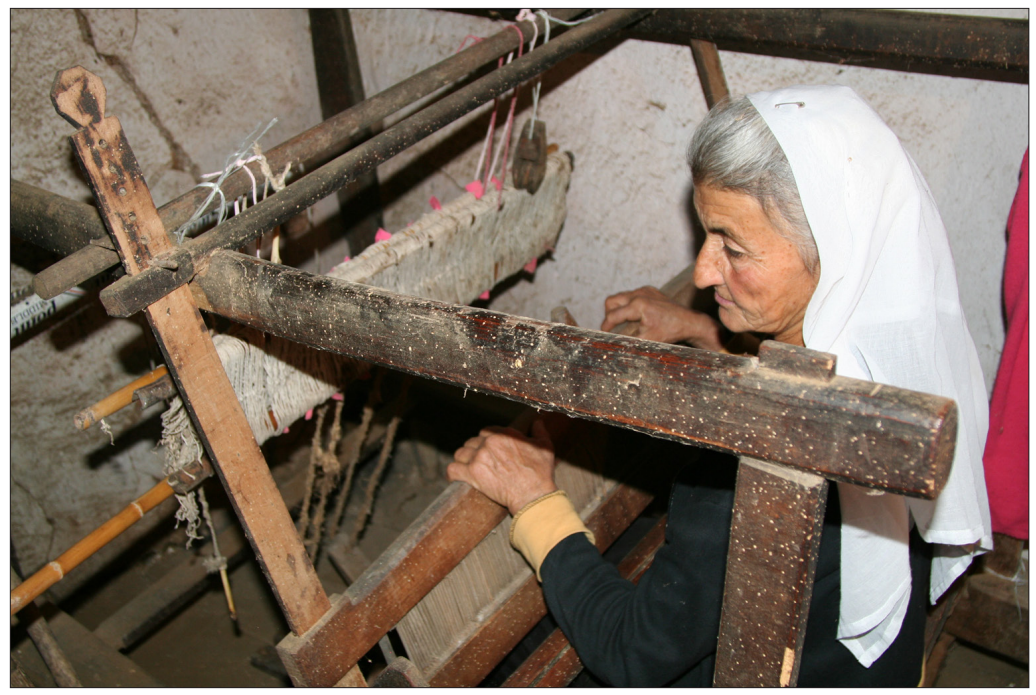

Figure 3. Aiša Lunić at a weaving loom in her old house. Village of Lunje. Photograph by Alexander Novik, September 2012.

First of all, traditional clothing has vanished almost completely from everyday use, while retaining its ritual status for the most important family events and calendrical rites (engagement, marriage, circumcision rite, funeral, KurbanBayram, and Ramazan-Bayram), for communal celebrations (village day, national holidays of Montenegro, group pilgrimages to holy places), for festivals such as Mrkovići Days, and for similar occasions. 
Secondly, members of the group have demonstrated a noticeably increased interest in their own history, culture, traditional dialect, and features of domestic lifestyle. This interest, among other things, stimulates development of folk arts and crafts, a development supported by the local administration. Whenever performances by contemporary folk groups involve folk dress, the notion of folk itself becomes subject to new interpretations, together with the real clothes that satisfy new demands under new conditions.

Thirdly, the standardized forms of culture and mentality promoted in a modern globalizing world provoke perennially new forms of opposition towards their homogenizing tendencies, while also exerting a considerable influence on material processes of costume transformation.

One approach to countering globalization can be seen when various ethnoconfessional groups actively assert their identity by striving to affirm their own distinctiveness and emphasize their differences from other groups. The Mrkovići represent an interesting example of such a group (Peročević 2005). Their costume is one of the most salient markers for emphasizing their unique status among neighboring Orthodox Montenegrins (cf. Mrvaljević 2006), Orthodox Serbs, Muslim Albanians, Catholic Albanians, Muslim Gorani, Muslim Gypsies, Muslim Turks, Muslim Bosniacs, and other groups.

\section{ON THE GENESIS OF THE MRKOVIĆI FEMALE COSTUME}

It has been established that for a number of decades following the Ottoman conquest in the 15th-16th centuries the coastal and mountain regions of South Dalmatia and Albania witnessed a competition between Venetian and Oriental fashion (Gjergji 1988). In this process, garments with trimmings and patterns imported from Istanbul and other major centers of the Ottoman Empire acquired a higher status. As a result, the dress worn by the multiethnic reference groups in the territories controlled by the Ottomans became dominated by the dress worn in Istanbul. The Mrkovići clothing was necessarily subjected to Muslim influence during the process of conversion to Islam in the 17th century; the Mrkovici, in declaring allegiance to Islam, would most likely have accepted the new prestigious Ottoman culture along with it. The costume, with its complex semantics and expressive significance, must have played a central role in a whole range of changes. We can assume that the costume worn by the Islamized Mrkovići resembled, in its basic features, the costume worn by the Turks (Muslims by definition in this time and region), ${ }^{2}$ by other Islamized Slavic groups (Čulić 1963), and by Muslim Albanians, their closest neighbors. 
The many ethno-local groups of Balkan peoples recently converted into a new faith usually devised their own clothing variants. On the one hand, they extensively borrowed forms, cuts, styles, technology, materials, and decorative solutions from the costume worn in Istanbul and other significant centers of the Muslim world. On the other hand, they also created clothing that conserved their own achievements in form and aesthetics, evaluating them in the light of new criteria for judging beautiful ugly, prestigious $\sim$ not prestigious, high status $\sim$ low status, right $\sim$ wrong. By marking the group's initiation into the predominant faith, these new costume variants helped establish the aesthetic perspectives of the dominating social group at all levels of local tradition. The changes encouraged members of the group to assign new meanings to particular elements and details of their clothing; in other words, common things in the culture changed their semiotic status.

The oriental costume prototype that existed in social reference groups in the capital (in particular among the Ottomans) became the most widespread variant of female dress among the Mrkovići. Albanian ethnography designates it as the "Middle Albanian Costume" (cf. Alb. Shqipëria e Mesme 'Middle Albania') (Shkodra 1973; Gjergji 1988; Statovci 2009; Onuzi $2015)^{3}$ (Fig. 4). It is prevalent over territories from the city of Durres on the coast of the Adriatic through the regions of Tirana and Elbasan to the territories of Metokhia, Kosovo, and western and northern Macedonia, including Skopje. This costume has been recorded in the northwest, around the cities of Shkodra (Serbo-Croatian Skadar), Ulcinj (Alb. Ulqini) and Bar (Alb. Tivari), among others - the three urban centers in the region settled by the Mrkovići.

Figure 4. Female festive costume, common among Muslims. The City of Bar Regional Museum (Zavičajni muzej Bar). Photograph by Alexander Novik, August 2013.

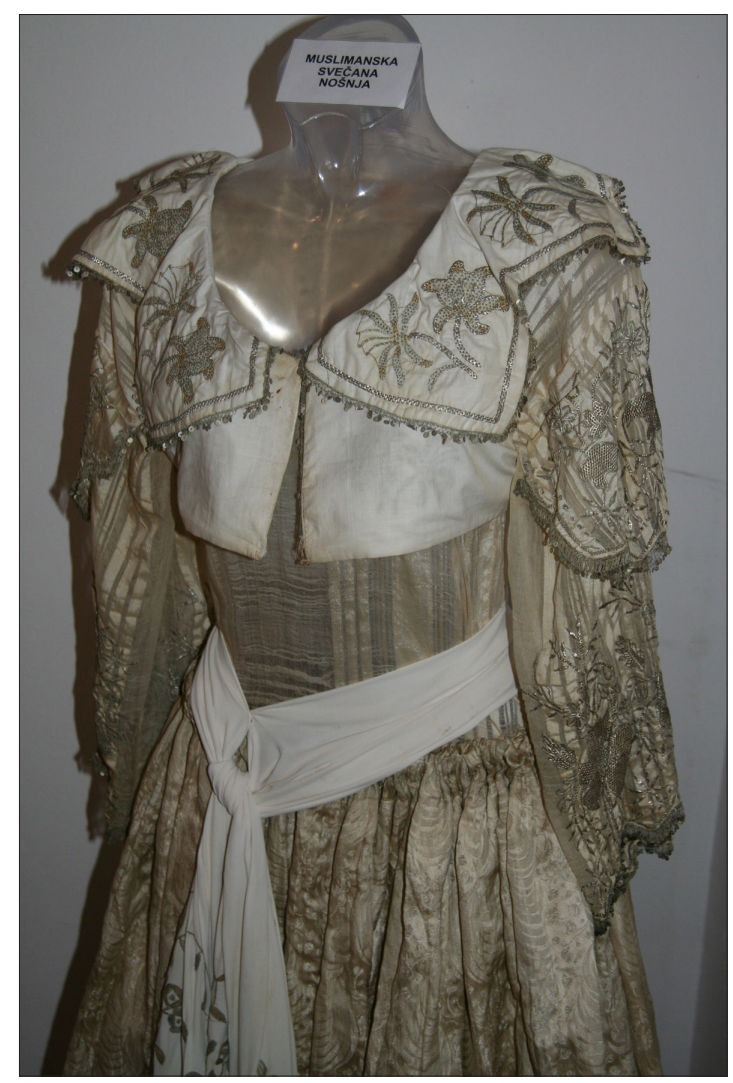




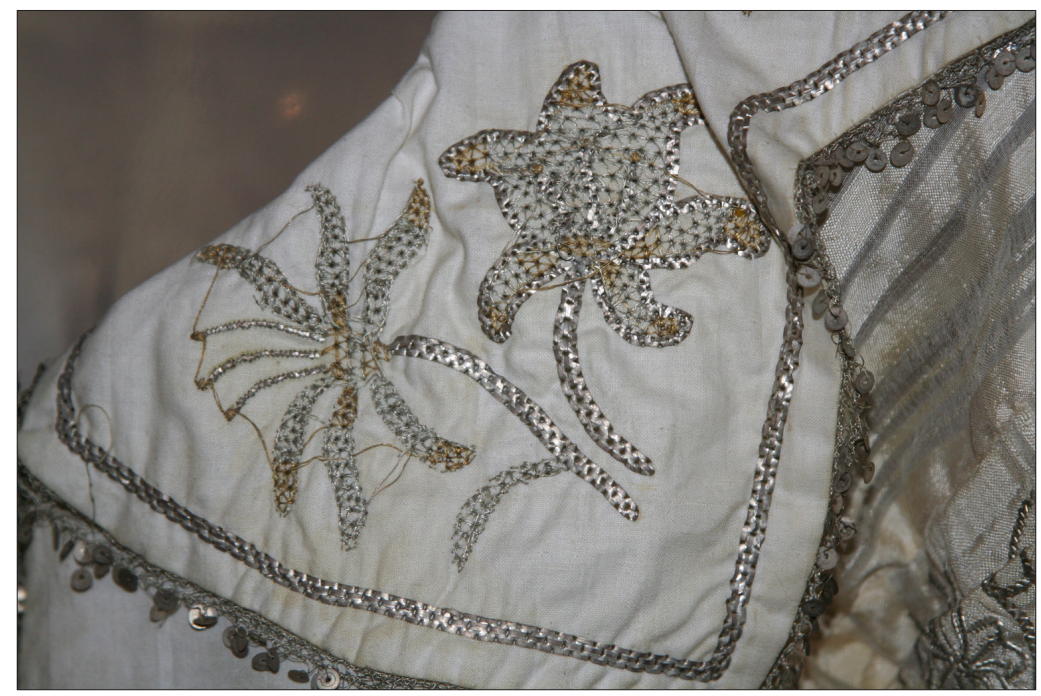

Figure 5. Embroidery detail on a džamadan waistcoat. The City of Bar Regional Museum (Zavičajni muzej Bar). Photograph by Alexander Novik, August 2013.

The prototypical Albanian oriental female costume consisted of the following elements: 1) dimi (a word borrowed directly from Turkish), loose pantaloons that often had different names in different places; 2) komza (in Gheg Albanian) to go with the dimi or kalce - gaiters of closely woven fabric with embroidery and sewing; 3) këmishë (from Latin camisia, which is a loan from Greek (Çabej 2014: 74)), a blouse made of thin fabric, usually silk; 4) jelek (a word borrowed from Turkish), a waistcoat of closely woven fabric, richly decorated with embroidery and sewing (Fig. 5); 5) two cloth belts of thin fabric, decorated with embroidery and sewing using the same colors applied to the waistcoat and gaiters; 6) a round cap of closely woven fabric or a kerchief made of thin silk fabric. The ensemble was completed by fancy shoes or slippers made of fabric or leather, or wooden-soled shoes called nallane (loan word from Turkish).

This costume type was worn exclusively by Muslim women and clearly indicated that its bearer belonged to the Mohammedan faith. Thus, for example, the peculiar version of the female Muslim costume developed in the city of Shkodra, which is traditionally subdivided into two main quarters (Catholic and Muslim), still includes the dimi. In fact, while up to 300 types of traditional clothing may be found in Albania (each krahina (region), city, or village, as a rule, has its own variant; sometimes several types of traditional clothing coexist in a single village) (Gjergji 1988), the costume that includes the dimi is universally recognized as a generalized type (prototype) of the female Muslim costume. 
The widespread, generalized type including the dimi has, nevertheless, specific features associated with various regions: in one place it is embroidered with gold, in another with silver; in some krahinas the costume is accompanied by a round cap, in others by a kerchief. Here it is necessary to emphasize that rural Muslim women have taken the dress of townswomen for a model. According to our informant's memories, the unified types of the female festive costume formed by the end of the 19th century in Bar and Ulcinj displayed no difference among those worn by Turkish townswomen, Albanians, and Slavic women converted to Islam.

\section{THE MRKOVIĆI FEMALE FESTIVE COSTUME IN THE 19TH-20TH CENTURIES}

In our fieldwork, we familiarized ourselves with exemplary costume artifacts from the collections of the regional museum in Bar, the archeological museum in Budva, and the ethnographic museum in Cetinje. We have studied authentic artifacts that represent local Mrkovići tradition, preserved in the school museum in the village of Pečurice (Fig. 6), and in the private collection of Bisera Alković in the village of Dobra Voda. We have also examined antique dress specimens kept in chests by local women, especially Aiša Lunić of the village of Lunje and

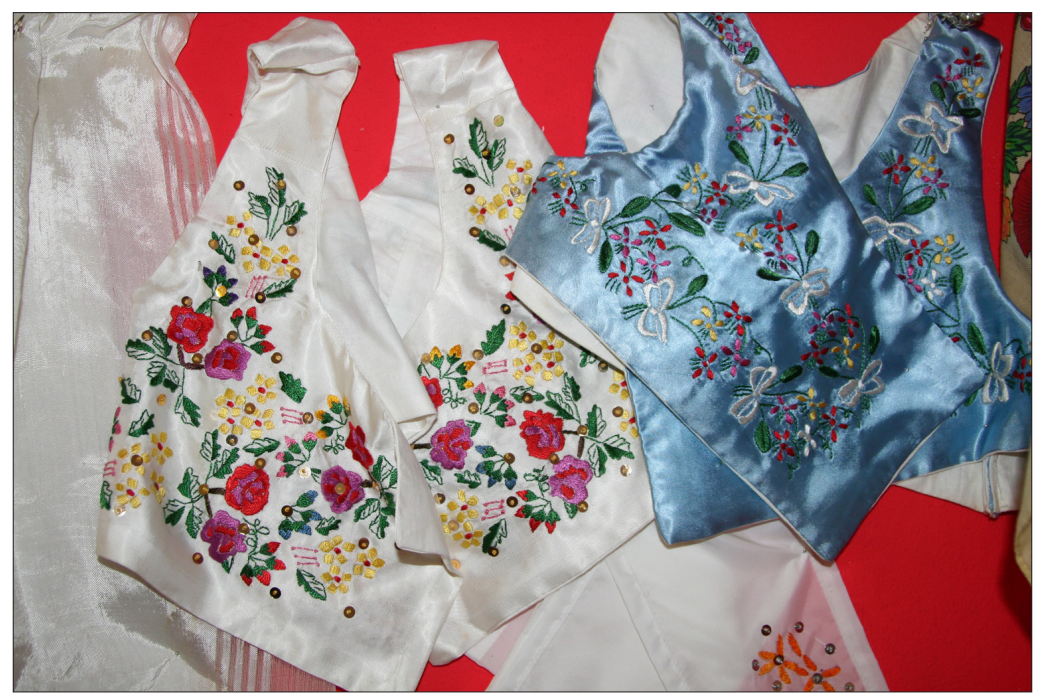

Figure 6. Ddžamadan waistcoats. 20th century. Museum of the village of Pečurice, Montenegro. Photograph by Alexander Novik, September 2012. 
Jasmina Dapčević of the village of Dabezići. Finally, we were able to gather a small but extremely illuminating collection of ten items, most of which relate to the traditional textile and clothing of the Mrkovići. These items, now part of the MAE collection, serve as an important resource, perhaps unique outside of Balkan Europe, for research on the production and use of folk dress in the region under investigation. ${ }^{4}$

The features that distinguish the Mrkovići clothing from the clothing worn by their Muslim neighbors who speak other languages ${ }^{5}$ have been described only for their everyday costume, in which the local character clearly stands out. We see this emphasis on distinctions in everyday dress as a rare phenomenon, because it is far more common for the burden of representing the local character to be carried completely by the most festive / celebratory / fancy/marriage variant. ${ }^{6}$ With the Mrkovići, these celebratory functions have been carried out by the prototypal Muslim female costume with the dimi designated as the costume of Middle Albania. It consists of the following elements:

1) brageše trousers (cf. Slovenian, Serbian, Croatian brageše, Albanian brakeshe (Skok 1971: 196; Vinja 1998: 64-65; Çabej 1976: 299-300; cf. Papahagi 1974 [1963]; Andriótis 1995; Ciorănescu 2001) from Venetian braga 'leather belt') made from thin white cotton fabric; the Mrkovići call it demija, but they believe this to be a Bosnian word;

2) fanjelica blouse of thin fabric, often silk (Fig. 7);

3) džamadan waistcoat (cf. Serbian džemadan 'chest buttoned waistcoat'; borrowed from Turkish (Skok 1971: 472)) made from dense fabric or thin fabric with a lining;

4) a gaiter of dense fabric or thin fabric with a lining;

5) pas trbulus silk belt (cf. Serbian, Bulgarian taraboloz; borrowed from Turkish, the toponym of Tarabulos, Tarabulus, Trablus 'Tripoli', where kerchiefs and belts were produced (Skok 1973: 490)) 5-7 meters in length and about $60 \mathrm{~cm}$ wide, wrapped around the waist (Fig. 8);

6) otos headgear (cf. Serbian, Bulgarian otoz (Georgiev et al. 1995: 967) and Albanian hotoz, borrowed from Turkish (Dizdari 2005: 396)), made from a colored šamija kerchief (a word borrowed from Turkish) and decorated with golden coins (Figs. 9-10);

7) footwear made of fabric or leather;

8) socks of white cotton yarn.

During the cold months the costume was supplemented by loose overcoats, socks of white wool, mantles, kerchiefs, etc. 


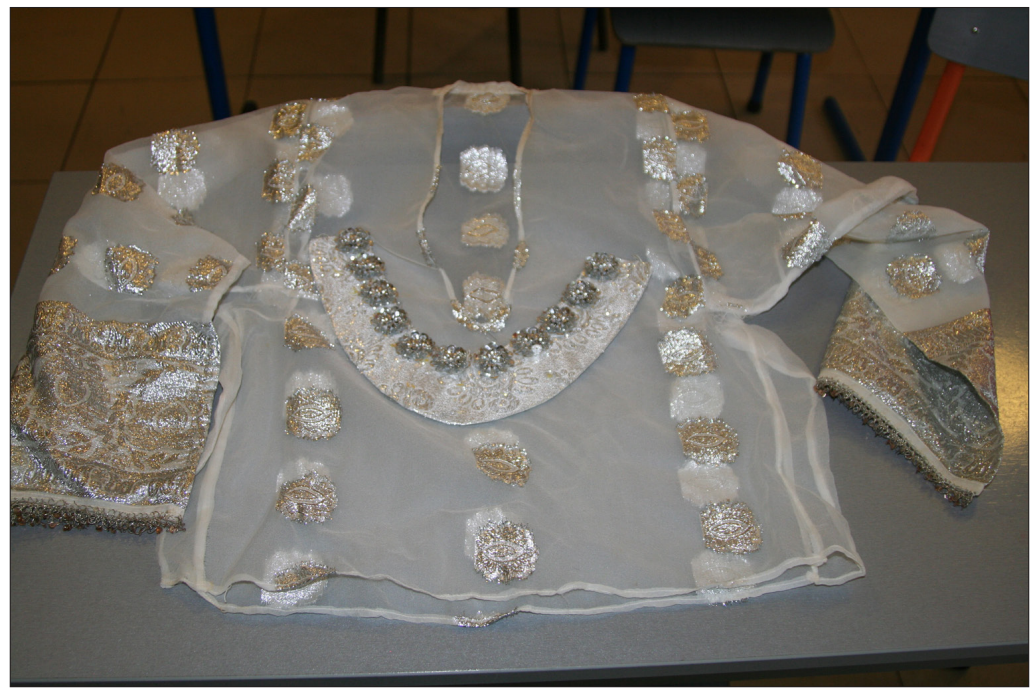

Figure 7. Fanjelica blouse. 20th century. Museum of the village of Pečurice. Photograph by Alexander Novik, September 2012.

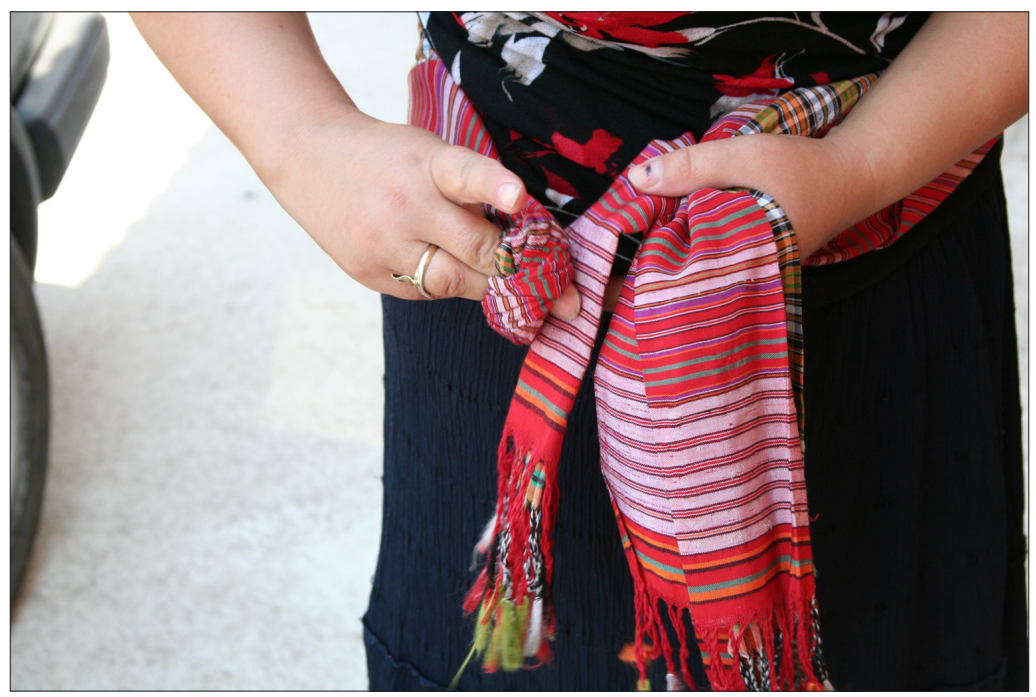

Figure 8. Pas trbulus belt. 20th century. Demonstrated by Jasmina Dapčević from the village of Dabezicii. Photograph by Alexander Novik, August 2013. 


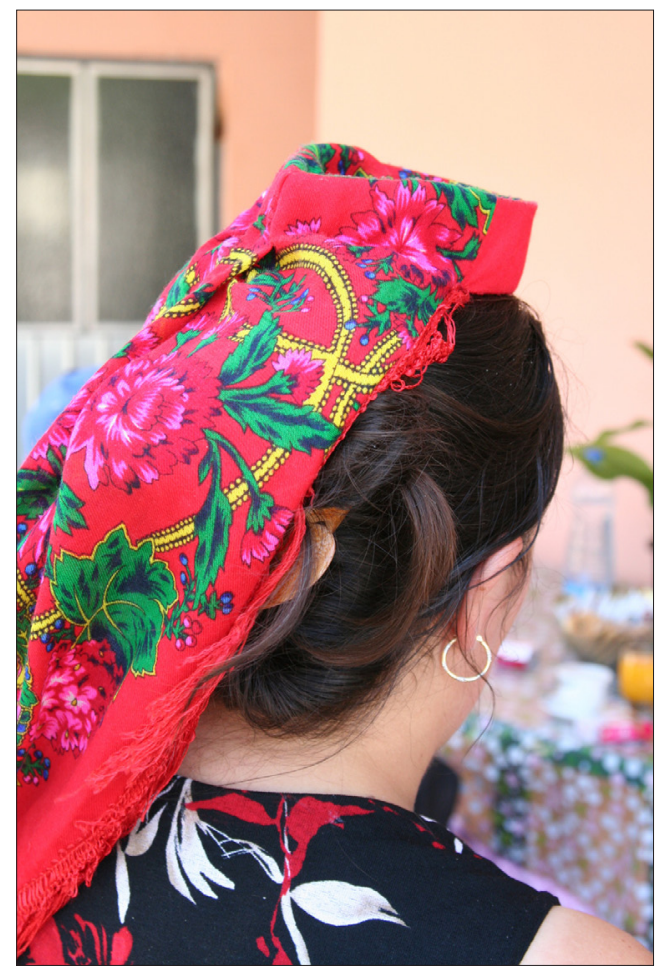

Figure 9. Otos headwear. 20th century. Demonstrated by Jasmina Dapčević from the village of Dabezici. Photograph by Alexander Novik, August 2013.

Figure 10. Silk jašmak kerchief covering an otos. 20th century. The two-element headpiece is demonstrated by Jasmina Dapčević from the village of Dabezici. Photograph by Alexander Novik, August 2013.

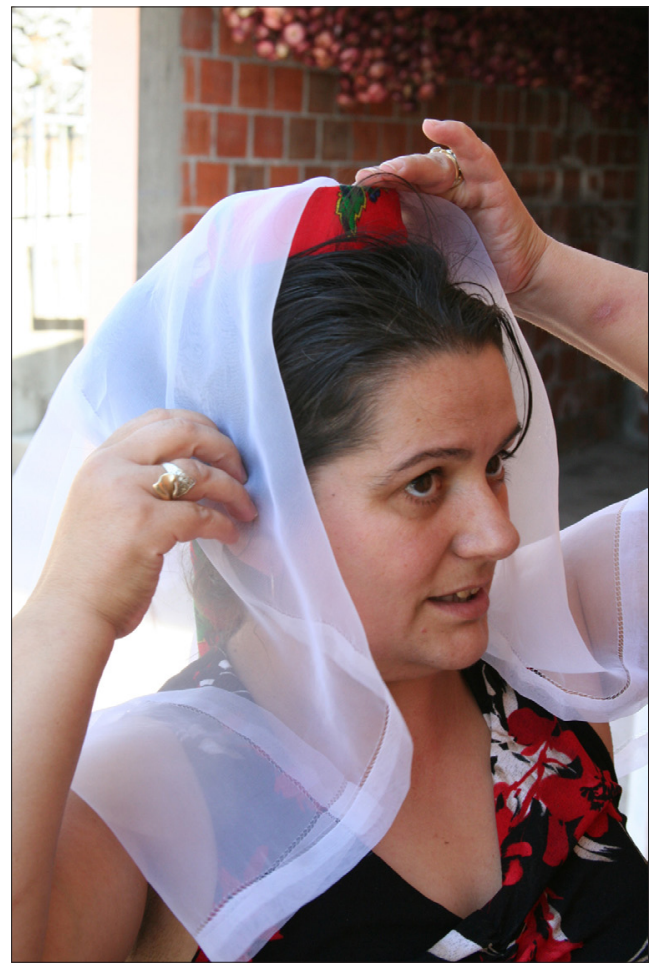


The costume variant described here remained unchanged until the beginning of the 20th century. Based on extant family pictures, reports from our informants, and literature on local history (Peročević 2005), it is possible to extend that continuity even further: during the whole of the 20th century, the costume with the dimi (Mrkovići brageše) maintained its function as ritual clothing among Muslim women (as a wedding costume, but also as the costume worn by the women - female relatives, close acquaintances, and female friends - invited to the marriage ceremony as guests), while a single female Muslim costume type persisted in the Bar region in its festive variant. ${ }^{7}$

\section{BREAK FROM TRADITION AND MODERN CHALLENGES}

The 20th century was marked by intense innovation in the spheres of the economic order, social relations, and traditional culture in the Western Balkans. Considerable changes happened to costume as well: the clothing previously in use (oriental in its origin, form, cut, and aesthetics) was first superseded in cities, but then everywhere and at virtually all levels by the forms and variants that go under the conventional name European dress in scholarly works dedicated to costume. This process became especially intensive after World War II, although male variants of the traditional clothing, for instance, had already been superseded by 'European' innovations in the first decades of the 20th century.

The new circumstances brought important changes to the Mrkovići female wedding costume. A significant innovation was the predominance of the color white in the whole ensemble: the majority of costume elements were now made of white fabric. The reasons for this change may be found in aesthetics, pragmatics, myth, and religion.

Firstly, the color white was always common for festive dress variants among many ethnic groups. It was considered pure, fancy, and beautiful (in the perspective of traditional aesthetic preferences). It was also considered 'expensive'when people saw a woman dressed in white, they perceived her as being dressed expensively because a white costume needed extra care and treatment that was not cheap by definition. This is why the practice of whitening shirt fabric or fabric for female trousers and other items made from linen, hemp, cotton, and Spanish broom (Lat. spartium junceum) was so common.

Secondly, the color white plays one of the most important and profound roles in Slavic color symbolism (Tolstoy 1995; Ajdačić 2001). It is also known in Islam as 'the color of Allah' and the white dress is considered 'Sunnah ${ }^{8}$ for living'. 
Thirdly, the elements of the festive costume variant were made of silk. As a rule, the fabric used was produced from naturally colored (light yellow or cream) silk thread. It was expensive to produce clothing, and according to the stereotypical attitudes taken in this society, silk clothing connoted high status and its natural color gained in prestige.

Fourthly, the invention of aniline dye in the 19th century and of synthetic fabric in the 20th century made it possible to produce almost perfectly white clothing. The most appealing snow-white color became available not only for the whitened linen, cotton, and other (hemp or juncus) fabric used for shirts, but also for the silk fabric used to make festive clothing.

Although white is found in the clothing ensembles of neighboring ethnic groups, none of them has as many white elements and costume details as the Mrkovići. The predominance of white in their costume is overwhelming. The traditional silk belts and waistcoats provide the only exceptions to this 'celebration of the color white'.

It is exceptionally important to note that men from some families of the Mrkovići tribe traditionally take Albanian women from the neighboring regions of Shestani, Ana e Malit, and Ulcinj as their brides (Jovičević 1922: 113). According to information gathered by A. Novik, the groom's family, in such cases, brings a complete traditional Mrkovići clothing ensemble to the Albanian bride's house as a wedding gift. The bride is expected to appear in this costume at the groom's house to partake in the wedding ceremony. After the wedding ceremony the costume becomes the new wife's festive clothing, marking her assimilation from another area and family into the Mrkovići community as a result of marriage. Even though it is possible that the young spouse does not speak and may never start speaking her husband's Slavic language, she wears the Mrkovići costume during holidays or important family celebrations. When the young wife departs to visit her relatives, however, she dresses in a costume characteristic of her own family and region.

During the expedition's work in the Dapčevići quarter of the village of Dabezići, we documented a complete wedding ensemble owned by Jasmina Dapčević (born into the Omeralovići family). The attire, worn by the female informant at her wedding in the 1960 s, corresponds in its elements to the prototypical festive variant of the Muslim female costume:

1) silk shirt - košulja od svile (Fig. 11);

2) cotton pantaloons-brageše pamučne (Fig. 12);

3) waistcoat - džamadan/jeleče (Fig. 13);

4) short inner shirt - potkošulja /fanjelica (Fig. 14);

5) red kerchief - šamija; 
Figure 11. Silk shirt. 20th century. Demonstrated by Jasmina Dapčević from the village of Dabezici. Photograph by Alexander Novik, August 2013.
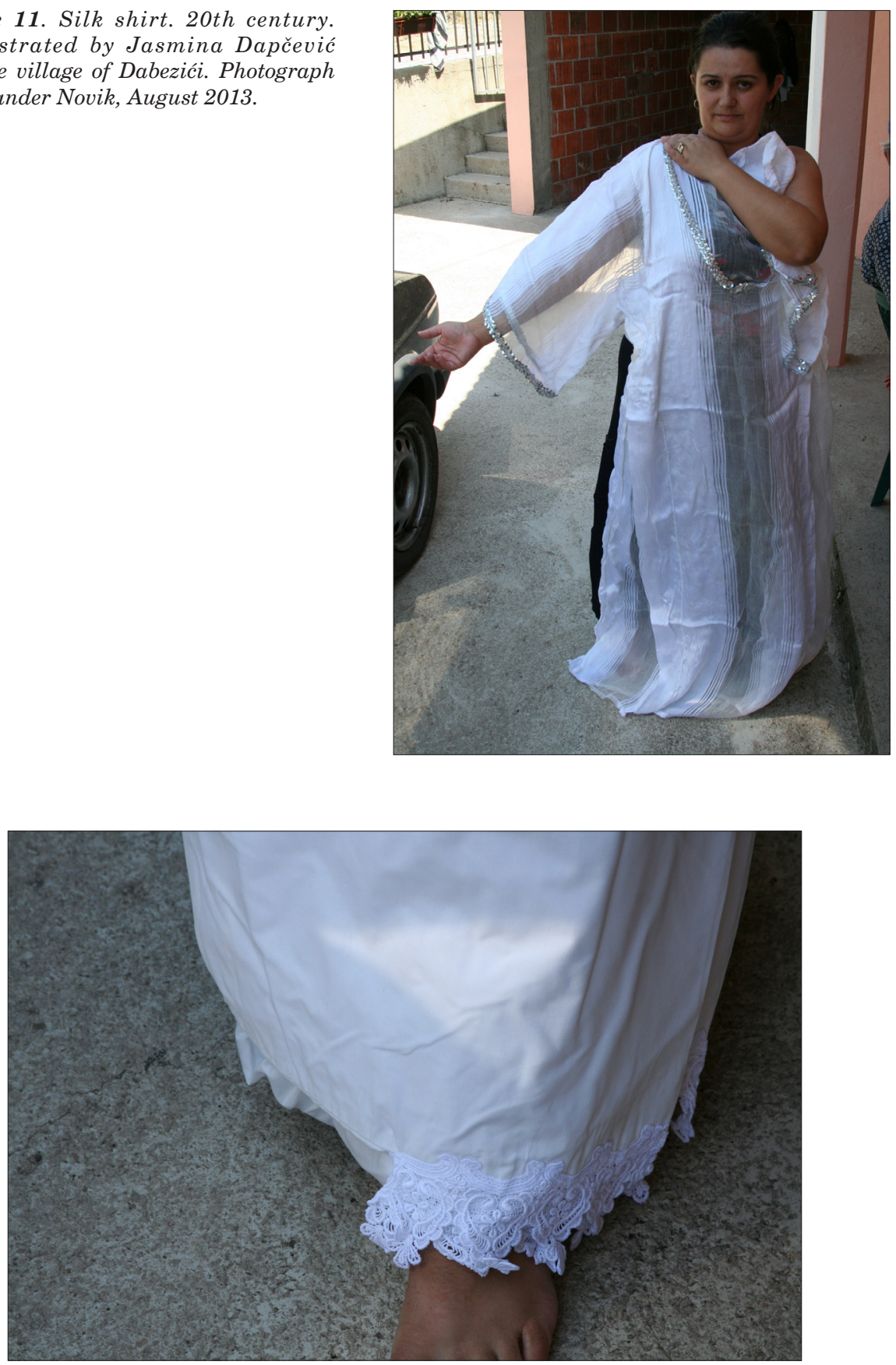

Figure 12. Brageše. Detail: decorative lacework. 20th century. Demonstrated by Jasmina Dapčević from the village of Dabezici. Photograph by Alexander Novik, August 2013. 


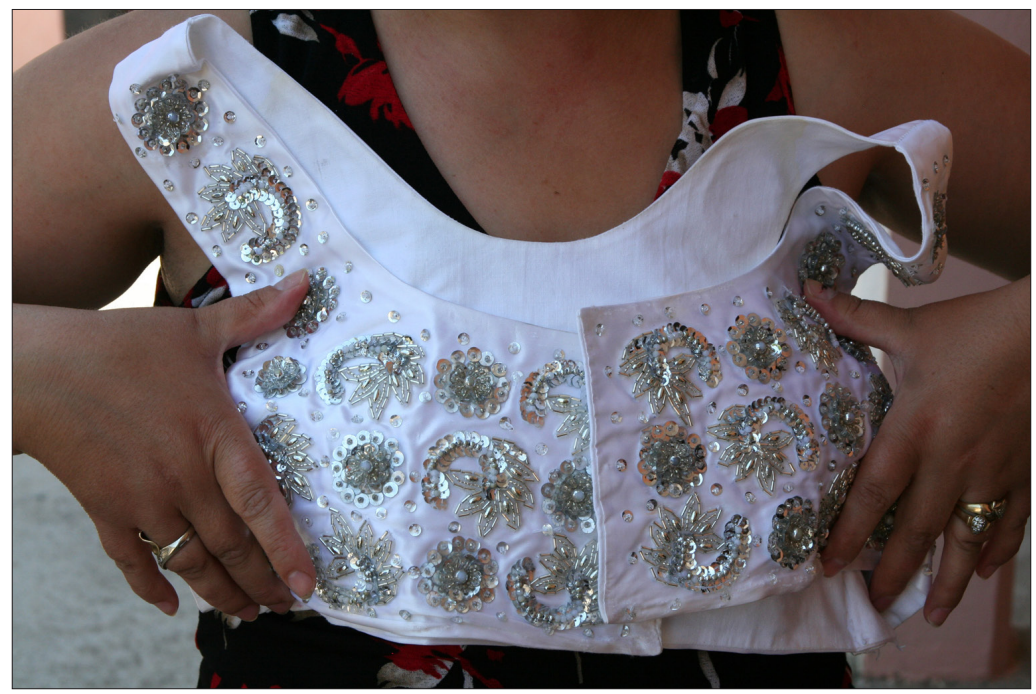

Figure 13. Džamadan/jeleče. 20th century. Demonstrated by Jasmina Dapčević from the village of Dabezicii. Photograph by Alexander Novik, August 2013.

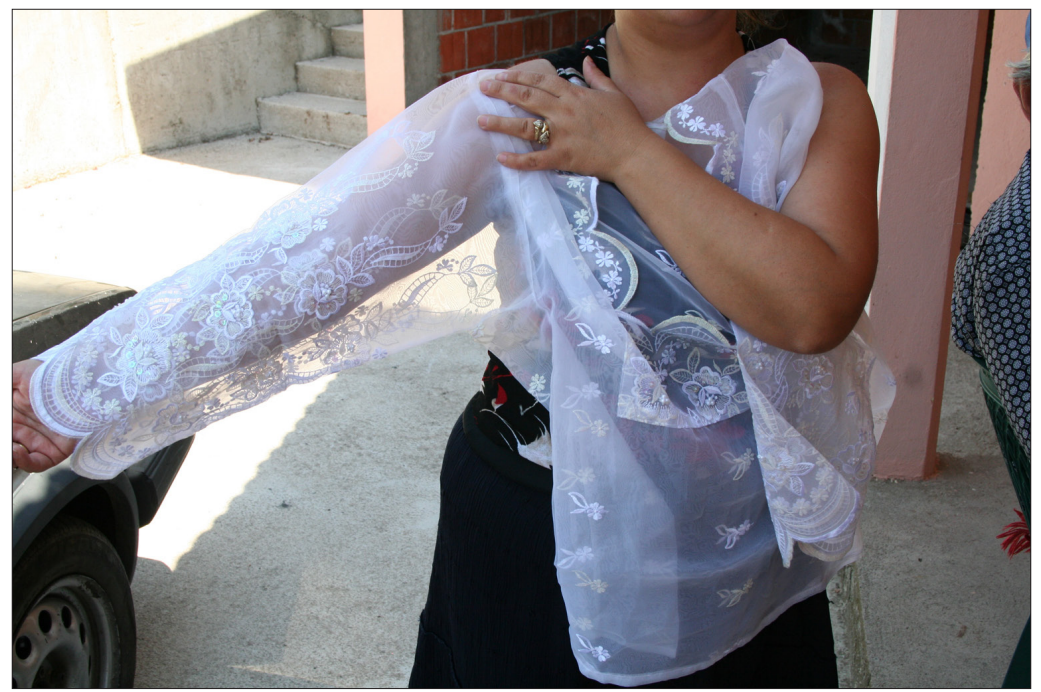

Figure 14. Potkošulja/fanjelica. 20th century. Demonstrated by Jasmina Dapčević from the village of Dabezići. Photograph by Alexander Novik, August 2013. 
6) silk head kerchief - jašmak svileni;

7) breast covering - siskač;

8) homemade silk belt - pas svileni;

9) a decoration made of gold coins or imitation coins - dukat (worn both on the breast or on the head kerchief).

Besides the predominance of the color white, the following elements of the ensemble can be singled out as its strongest distinguishing features:

a) two variants of headgear: red bridal wear for the marriage ceremony and a white head kerchief for a married woman (both are perceived by the informants as necessary components of a complete ensemble);

b) waistcoat (most commonly white in a wedding costume, sewn with gold and silver decoration or metallic thread embroidery);

c) obligatory homemade silk belt patterned in many colors; red must predominate.

Similar wedding ensembles have been documented in various areas settled by the Mrkovići, based on the evidence of modern wedding photographs (Fig. 15)

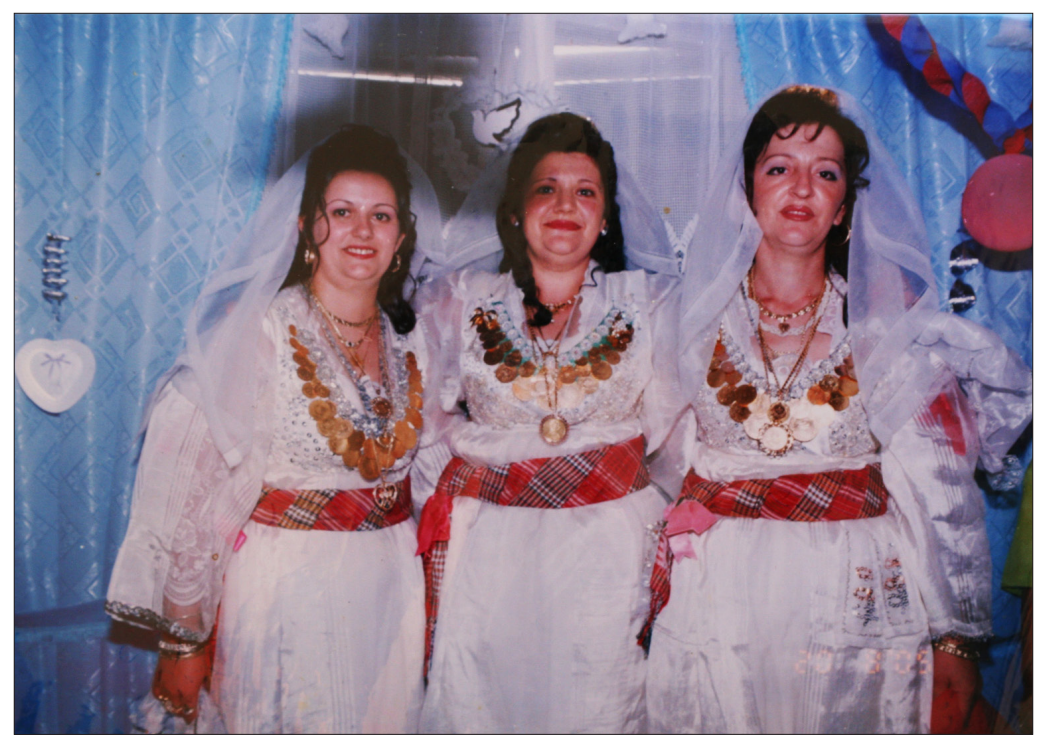

Figure 15. Mrkovići women in traditional wedding costumes. Village of Dabezići, 20th century. Picture from Jasmina Dapčević's family album. Photograph by Alexander Novik, August 2013. 
and videos that show almost all brides wearing identical dress. Modern Mrkovići brides do not make their own wedding clothes, as they still did even in the 1950 s, according to informant Aiša Lunić from the village of Lunje. Rather, they purchase the ensembles from local craftswomen who specialize in sewing wedding and festive garments, following local traditions and expectations. Data from A. Novik implies that currently two such seamstresses are working in the region.

We ought to mention that local Mrkovići activists and regional history experts, who wish to promote their own ethno-local culture and assert their group's unique status in the region, have initiated attempts to create a costume type different from those of their neighbors. ${ }^{9}$ As a result, the costumes worn by contemporary folk performers are frequently made up according to amateurish subjective notions of what is proper rather than sewn according to the pattern of older prototypes. This process of inventing tradition under the banner of revitalizing realia and phenomena that symbolize and distinguish the culture of a certain group resembles processes taking place in other regions of the world.

\section{CONCLUSION}

The small ethno-local and ethno-confessional community of the Mrkovići in Montenegro, while maintaining linguistic, confessional, and political contact among its own members, preserves close relations, including blood ties, with Slavic and Albanian populations in Montenegro, Bosnia and Herzegovina, Serbia (Sandžak region), and Albania. Group identity among the Mrkovići is marked by realia, ritual practices, attitudes, lifestyle, and the organization of everyday affairs characteristic of the Muslim population of the Western Balkans as a whole, which are also historically oriented towards multiethnic reference groups of the Ottoman Empire. Specifically, the traditional Mrkovići female costume, derived from prototypical Muslim clothing with the dimi (loose pantaloons), is a product of multiethnic and multicultural creation of new forms and aesthetic preferences. Nevertheless, the awareness of group unity, specific local dialect, multiple Slavic cultural and linguistic archaisms, Romance, Ottoman, and Albanian borrowings, europeisms, as well as their own oftentimes unique new creations shape the inimitable profile of the Mrkovici language and culture, represented in this article by such a salient marker of local identity as the traditional wedding costume.

Through the last several decades, the basic costume has, on the one hand, survived substantial innovations in the color palette, where the color white now 
Figure 16. Aiša Lunić in a traditional jašmak kerchief and modern clothing. Village of Lunje. Photograph by Alexander Novik, September 2012.
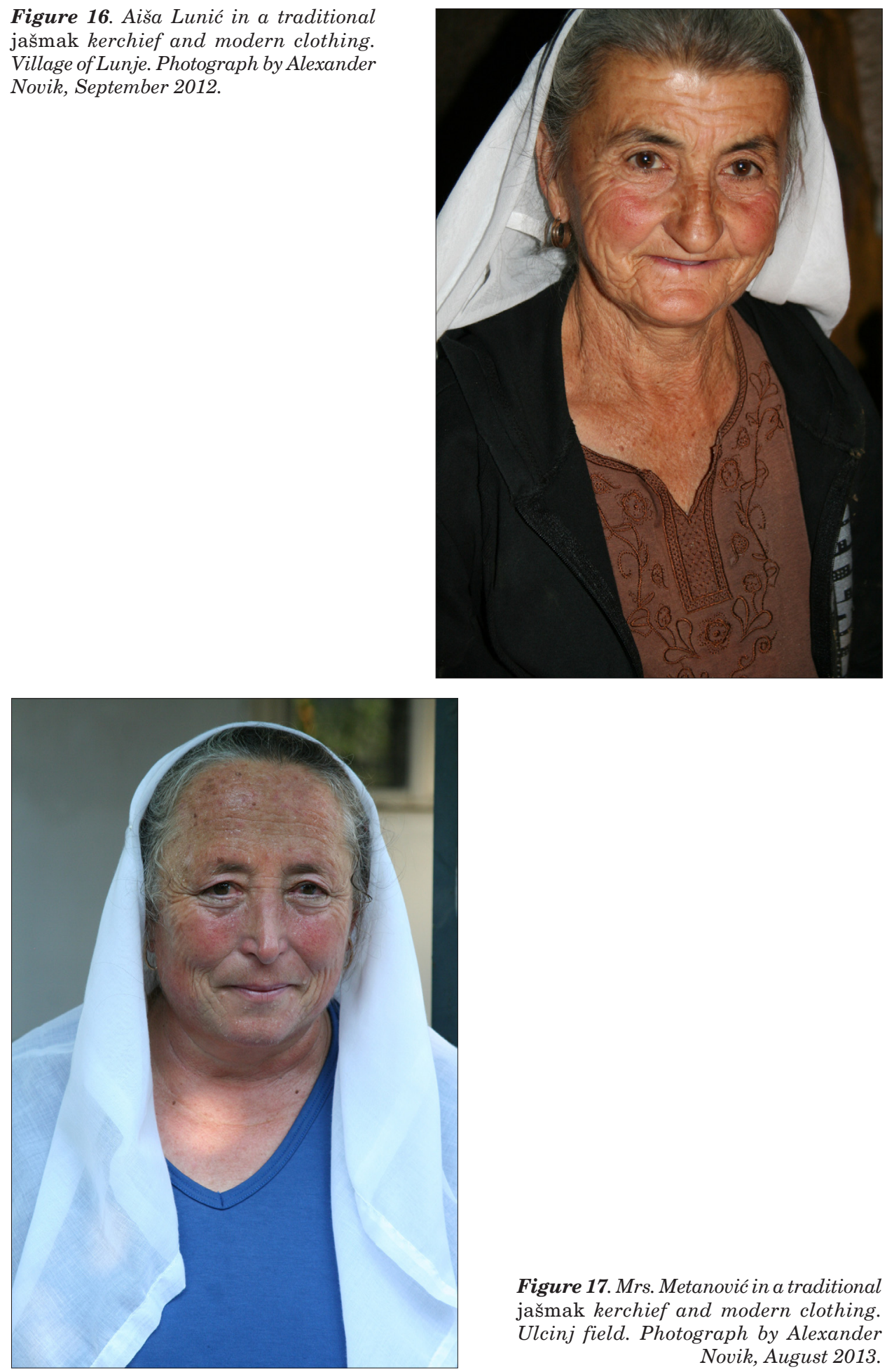

Figure 17. Mrs. Metanović in a traditional jašmak kerchief and modern clothing. Ulcinj field. Photograph by Alexander Novik, August 2013. 


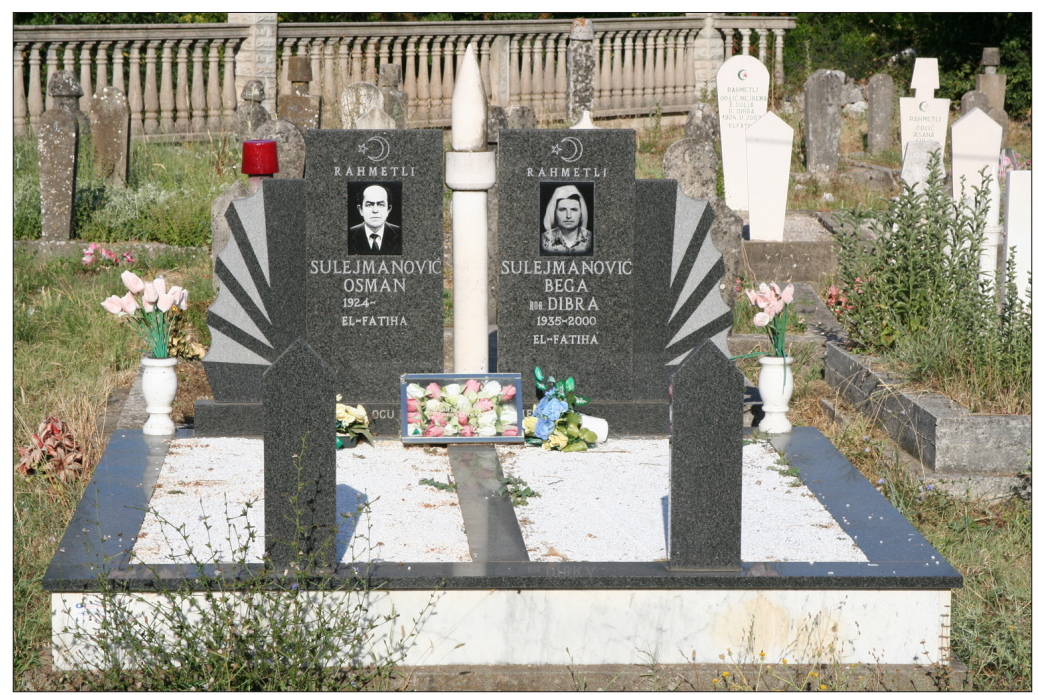

Figure 18. Sepulcher in a graveyard in the village of Mala Gorana. Portrait on the sepulcher: a deceased woman in a traditional kerchief. Photograph by Alexander Novik, August 2013.

predominates, as well as innovations in cut, choice of materials, and decorations, among other things (Figs. 16-18), while, on the other hand, conserving such elements as the otos (headgear) and pas trbulus (belt). The traditional Mrkovici wedding costume makes this ethno-confessional group clearly distinct when contrasted with the clothing of other ethnic communities in the region, and there is every reason to believe that the costume not only maintains its symbolic, cultural, confessional, and social role, but will continue to do so for a long time. 


\section{ACKNOWLEDGEMENTS}

Research for this article was funded by a grant from the Russian Science Foundation (the project titled From separation to symbiosis: Languages and cultures of south-east Europe in contact, № 14-18-01405). The authors are grateful to Snežana Petrović of the Serbian Language Institute in Belgrade for a series of valuable contributions concerning etymology.

\section{NOTES}

1 From a national and political standpoint, the Mrkovici could be identified as Muslim Slavs, Bosniacs, Montenegrins, or Serbs, while naming Serbo-Croatian, Bosniac, Montenegrin, or Serbian as their language. The issue of the Mrkovići's beliefs about the degree of unity among Slavic Muslim groups and their cultures in Montenegro, Bosnia and Herzegovina, and Serbia is a subject of future research (see Uzeneva 2014). What is important for the current study is the explicitly stated awareness of community among all of the Mrkovići.

2 The Ottomans comprised the administrative, economic, military, judiciary, and clerical elites of the society in almost every region of the extensive empire.

3 We should point out that a new classification for the types of Albanian traditional female wear, more detailed than the one suggested by Andromaqi Gjergji (1988), has been proposed by Afërdita Onuzi (2015). Following the new classification, as we do in our work, the costume worn by Muslim women in the city of Ulcinj constitutes a separate type.

4 The field materials produced by the expedition (audio files with interview recordings, field logs and journals, pictures) as well as the items of traditional culture collected during it have provided a basis for the new collection of the Department of European Studies of the MAE "Kunstkamera" RAS. The collection will function both as a research aid and, fulfilling the intention of the research community, as a supplement to the collection of the Minor dialectological atlas of Balkan languages (Russ. MDABYa) (Ermolin 2014) archived by the museum.

5 We do not have space in this paper to delve more deeply into elaborating on such obvious facts as the differences between Muslim and Christian clothing in the Western Balkans, which fundamentally determined both clothing construction (arrangement of elements, style, etc.) and aesthetics (color palette, decoration, etc.).

${ }^{6}$ In the majority of local traditions in the Balkans the fanciest variant of their costume - the marriage costume - also holds a festive status. After the marriage ritual the woman begins to wear the dress she wore during the marriage ceremony in public places on holidays, family celebrations, important events and so on (if the costume wears out, begins to fade or look shabby, or no longer fits, it is replaced by a costume 
completely identical in style and arrangement, preserving the tradition). Nevertheless, a number of ethno-confessional and ethno-local groups have different costumes for marriage and for other celebrations. The festive costume may differ from the wedding costume in one or several elements, most commonly addition or removal of headgear, head drape, or belt. In this article we refer to this kind of costume, in general, as the 'marriage costume', keeping in mind its other possible functions and variations on other occasions.

7 The variety (in form, cut, etc.) of various elements and details, as well as the choice of the color palette for decorations served to indicate ethnic and local identities.

8 The body of traditional social and legal custom and practice of the Islamic community.

9 We have not been able to address in this article an immensely important factor that affects the economic and cultural development of the Mrkovići: migration to the USA and back. Elements of traditional culture are present in the life of the big Mrkovići community in Chicago (see the activities of the cultural center Rumija) and the practices associated with this community exert an influence on their fellow countrymen in Montenegro.

\section{REFERENCES}

Ahmetaj, Mehmet 2006. E folmja e Anës së Malit. [The Local Dialect of Ana e Malit.] Prishtinë: Instituti Albanologjik i Prishtinës.

Ajdačić, Dejan 2001. Bibliografija o bojama u narodnoj kulturi Slovena. [Bibliography of Colors in the Slavic Folk Culture.] Kodovi slovenskih kultura, Vol. 6, pp. 166-177. Available at http://www.rastko.rs/rastko/delo/11781, last accessed on September 27, 2016.

Andriótis, Nikoláos P. 1995. Etimoloyikó lexikó tis kinís neoellinikís. [Etymological Dictionary of Standard Modern Greek.] Thessaloníki: Aristotélio Panepistímio.

Çabej, Eqrem 1976. Studime etimologjike në fushë të shqipes. [Etymological Studies in the Field of Albanian Language.] Bleu II. A-B. Tiranë: Akademia e Shkencave e RPS të Shqipërisë, Instituti i Gjuhësisë dhe i Letërsisë.

Çabej, Eqrem 2014. Studime etimologjike në fushë të shqipes. [Etymological Studies in the Field of Albanian Language.] Bleu V. K-M. Tiranë: Akademia e Shkencave e RPS të Shqipërisë, Instituti i Gjuhësisë dhe i Letërsisë.

Ciorănescu, Alexandru 2001. Dicţionarul etimologic al limbii române. [Etymological Dictionary of Romanian Language.] Bucureşti: Saeculum.

Čulić, Zorislava 1963. Narodne nošnje u Bosni i Hercegovini. [Folk Costumes in Bosnia and Herzegovina.] Sarajevo: Zemaljski muzej.

Dizdari, Tahir M. 2005. Fjalor i orientalizmave në gjuhën shqipe. [Dictionary of Oriental Loanwords in the Albanian Language.] Tiranë: AIITC.

Ermolin, Denis 2014. Rukopisnyi arkhiv malogo dialektologicheskogo atlasa balkanskikh iazykov. [Manuscript Archive of the Minor Dialectal Atlas of the Balkan Languages.] Unedited manuscript. St. Petersburg: MAE RAN. 
Georgiev, Vladimir et al. (eds.) 1995. B"lgarski etimologichen rechnik. [Bulgarian Etymological Dictionary.] Vol. IV: Mingo²-Padam. Sofia: Marin Drinov.

Gjergji, Andromaqi 1988. Veshjet shqiptare në shekuj. Origjina. Tipologjia. Zhvillimi. [Albanian Costumes through the Centuries: Origin, Typology, Evolution.] Tiranë: Akademia e Shkencave e Shqipërisë.

Grgurević, Osman 2013. Mrkojevići: Osnovne geografske karakteristike. [Mrkojevići: Main Geographical Characteristics.] Unedited manuscript. Ulcinj.

Jovičević, Andrija 1922. Crnogorsko Primorje i Krajina. [Montenegrin Primorje and Krajina.] Srpski etnografski zbornik. [Collected Articles on Serbian Ethnography.] Vol. XXIII. Beograd: SANU, pp. 1-172.

Metanović, Mahmut 2001. Mrkovići: istorijski razvoj. [Mrkovići: Historical Development.] Unedited manuscript. Nikšić.

Metanović, Mahmut 2005. Mrkovići, krajem XIX početkom XX vijeka. [Mrkovići: End of the 19th - Beginning of the 20th Century.] Unedited manuscript. Nikšić.

Mrvaljević, Zorica 2006. Crnogorska narodna nošnja. [The National Costume of Montenegro.] Podgorica: Muzeji i galerije.

Onuzi, Afërdita 2015. Kostume tradicionale shqiptare: Tradita vazhdon. [Albanian Traditional Costumes: Continuing Tradition.] Tiranë: Ministria e kulturës.

Papahagi, Tache 1974 [1963]. Dicţionarul dialectului aromîn, general şi etimologic. [Dictionary of Aromanian Dialect, General and Etymological.] Bucureşti: Editura Academiei.

Peročević, Ethem 2005. Mikulići na kraju vijeka. [Mikulići at the End of the Century.] Bar: Udruženje Mikulića.

Shkodra, Zija 1973. Esnafet shqiptare (shekujt XV-XX). [The Albanian Esnafs (15th-20th Centuries).] Tiranë: Akademia e Shkencave e R.P. të Shqipërisë.

Skok, Petar 1971. Etimologijski rječnik hrvatskoga ili srpskoga jezika. [Etymological Dictionary of Croatian or Serbian.] Knjiga prva. A-J. Zagreb: JAZU.

Skok, Petar 1973. Etimologijski rječnik hrvatskoga ili srpskoga jezika. [Etymological Dictionary of Croatian or Serbian.] Knjiga treća. Poni-Ž. Zagreb: JAZU.

Sobolev, Andrey \& Novik, Aleksandar (eds.) 2013. Golo Bordo (Golloborde), Albaniia: Iz materialov balkanskoi ekspeditsii RAN i SPbGU 2008-2010 gg. [Golo Bordo (Gollobordë), Albania. Materials of the Balkan Expedition of the Russian Academy of Sciences and St. Petersburg State University 2008-2010.] St. Petersburg: Nauka; Munich: Otto Sagner Verlag.

Statovci, Drita 2009. Veshjet shqiptare të Kosovës. [Kosovo Albanians' Costumes.] Prishtinë: Instituti Albanologjik.

Šekularac, Božidar \& Pavlović, Cvetko 2012. Toponimija opštine Bar. [Toponyms of Bar Municipality.] Podgorica: DANU.

Tolstoy, Nikita 1995. Belyi tsvet. [The Color White.] In: Nikita Tolstoy (ed.) Slavianskie drevnosti: Etnolinguisticheskii slovar'. [Slavic Antiquities: Ethno-Linguistic Dictionary.] Vol. 1: A-G. Moscow: Mezhdunarodnye otnosheniia, pp. 151-154.

Uzeneva, Elena (ed.) 2014. Slaviane-musul'mane na Balkanakh: iazyk, kul'tura, identichnost'. [Slavic Muslims in the Balkans: Language, Culture, Identity.] Moscow: ISl RAN. 
Vinja, Vojmir 1998. Jadranske etimologije: Jadranske dopune Skokovu etimologijskom rječniku. [Adriatic Etymologies: Adriatic Supplement to Skok's Etymological Dictionary.] Knjiga I. A-H. Zagreb: HAZU \& Školska knjiga.

Vujović, Luka 1969. Mrkovićki dijalekat. [Dialect of Mrkovići.] Srpski dijalektološki zbornik. [Collected Articles on Serbian Dialectology.] Knj. XVIII. Beograd: SANU, pp. 73-399. 